\title{
The US and Chinese Foreign Direct Investment in Africa
}

\author{
Baban Hasnat \\ State University of New York, Brockport, NY, USA
}

\begin{abstract}
This paper compares the patterns of the US and Chinese outward foreign direct investment (FDI) in Africa. The main objective of the paper is to examine if the motives for FDI for these two countries differ. This is done first with a descriptive analysis and then with empirical research. It reveals that Africa attracts only a small fraction of FDI from both the US and China. However, compared to the US, China's FDI outflow to Africa is rising rapidly. It was only $8 \%$ of the US outward FDI in 2006, but is about 20\% in 2010. Based on the standard FDI literature, the paper then investigates the determinants of FDI for both the US and China empirically. Hypotheses are developed and tested using ordinary least squares regression methods. Data are annual averages for the period 2003-2010. They are gathered from various standard sources such as the World Bank, The United Nations Conference on Trade and Development (UNCTAD), and the Chinese government. The paper finds expected result for market size, resource endowment, corruption, and openness. Chinese investment in Africa is often viewed as their desire to control natural resources, but the paper finds that the US investment is no different in this regard. The paper's finding contradicts with the popular perception that Chinese outward FDI ignores corruption or attracted to countries with higher level of corruption. With respect to political risk, the paper finds that Chinese FDI flow is not significantly different from the US FDI flow.
\end{abstract}

Keywords: foreign direct investment (FDI), USA FDI in Africa, Chinese FDI in Africa, US vs. Chinese FDI

\section{Introduction}

Foreign direct investment (FDI), which involves investment in resources in business activities abroad, has been a major force in the shift toward an integrated and interdependent world economy. While there is general consensus on FDI's importance in the world economy, there is disagreement on why certain areas and countries attract FDI than others. Currently a hot topic in the FDI literature is what attracts FDI in Africa. The subject generated worldwide attention, concern, and controversy after major investments in Africa by China, a new kid on the block in international investment. Scholars and policymakers are not quite sure how to explain China's interest in Africa. Chinese investments are often viewed with a mixture of hope and fear: hope because it brings in resources and creates jobs, and fear because it may lead to surrendering control over natural resources. These mixed feelings are often based on anecdotal evidence and personal opinion. There is thus a need for a systematic empirical research to provide a better understanding of the phenomenon. According to conventional wisdom, China's need for a steady supply of resources for its growing economy largely explains its eagerness

Baban Hasnat, Professor of International Business and Economics, Department of Business Administration, the College at Brockport, State University of New York.

Correspondence concerning this article should be addressed to Baban Hasnat, Department of Business Administration, the College at Brockport, State University of New York, 350 New Campus Drive, Brockport, NY 14420, USA. E-mail: bhasnat@brockport.edu. 
to invest in Africa. Are not the US or other European countries doing the same? It appears that the increasing Chinese presence has intensified the scramble for African resources. The purpose of this paper is to shed some lights in this area by examining the determinants of the US and Chinese outward FDI in Africa. Are the determinants different for the US and China?

\section{The US and Chinese FDI: A Descriptive Overview}

Historically, Africa has attracted very little FDI. Table 1 shows the stock of inward FDI in Africa in selected recent years. Not surprisingly, Africa's share of worldwide FDI is less than 3\% in 1990, 2000, and 2010. The value of FDI stock in the Netherlands alone was more than the stock of FDI in the entire African continent.

Table 1

Stock of FDI in Africa, 1990-2010 (At Current Prices and Exchange Rates, in Millions of US Dollar)

\begin{tabular}{lccc}
\hline Region & 1990 & 2000 & 2010 \\
\hline World & $2,081,299$ & $7,445,637$ & $19,140,603$ \\
Africa & 60,675 & 154,268 & 553,972 \\
North Africa & 23,962 & 45,728 & 206,067 \\
West African & 14,013 & 33,401 & 95,396 \\
Central Africa & 3,808 & 5,733 & 38,835 \\
East Africa & 1,701 & 7,199 & 30,913 \\
Southern Africa & 17,191 & 62,208 & 182,762 \\
Africa (\%) & 2.92 & 2.07 & 2.89 \\
Netherlands & 68,731 & 243,733 & 589,825 \\
\hline
\end{tabular}

Note. Source: UNCTAD online database (Retrieved from http://unctadstat.unctad.org/TableViewer/tableView.aspx).

Figure 1 shows the aggregate flow of FDI in Africa from 1995 to 2011. It increased gradually from 1995 to 2004 , from about $\$ 5.7$ billion to $\$ 15.7$ billion. Then in the next four years, flows increased rapidly, by more than threefold to all time high $\$ 56$ billion in 2008. Since then, flows have declined and most likely bottomed out to about $\$ 40.2$ billion in 2011. The negative growth in FDI flows in Africa during 2008-2011 was partly caused by political unrests in North Africa, which traditionally receives about one-third of all FDI flows in Africa (United Nations Conference on Trade and Development, 2012).

Africa attracts a very small percentage of total FDI flow in the world (see Figure 2). In fact, its average share of FDI during 1995-2011 was only 2.25\%. The share reached an all-time high to $4.13 \%$ in 2009 . The distribution of FDI among the African countries is highly skewed with Nigeria, South Africa, and Ghana each receiving over $\$ 3.0$ billion in 2011. Nigeria accounted for over $20 \%$ of all flows to the continent. While Angola received FDI inflows worth over $\$ 10$ billion in gross terms, divestments and repatriated income left its inflow

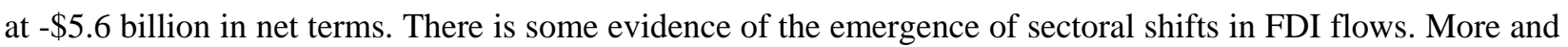
more FDI went to diversification of natural resource-related activities and less toward the extractive industries. Aside from the construction industry, increasing amount of FDI flowed to electric, gas, and water distribution, and transportation, storage, and communication sector (United Nations Conference on Trade and Development, 2012). 


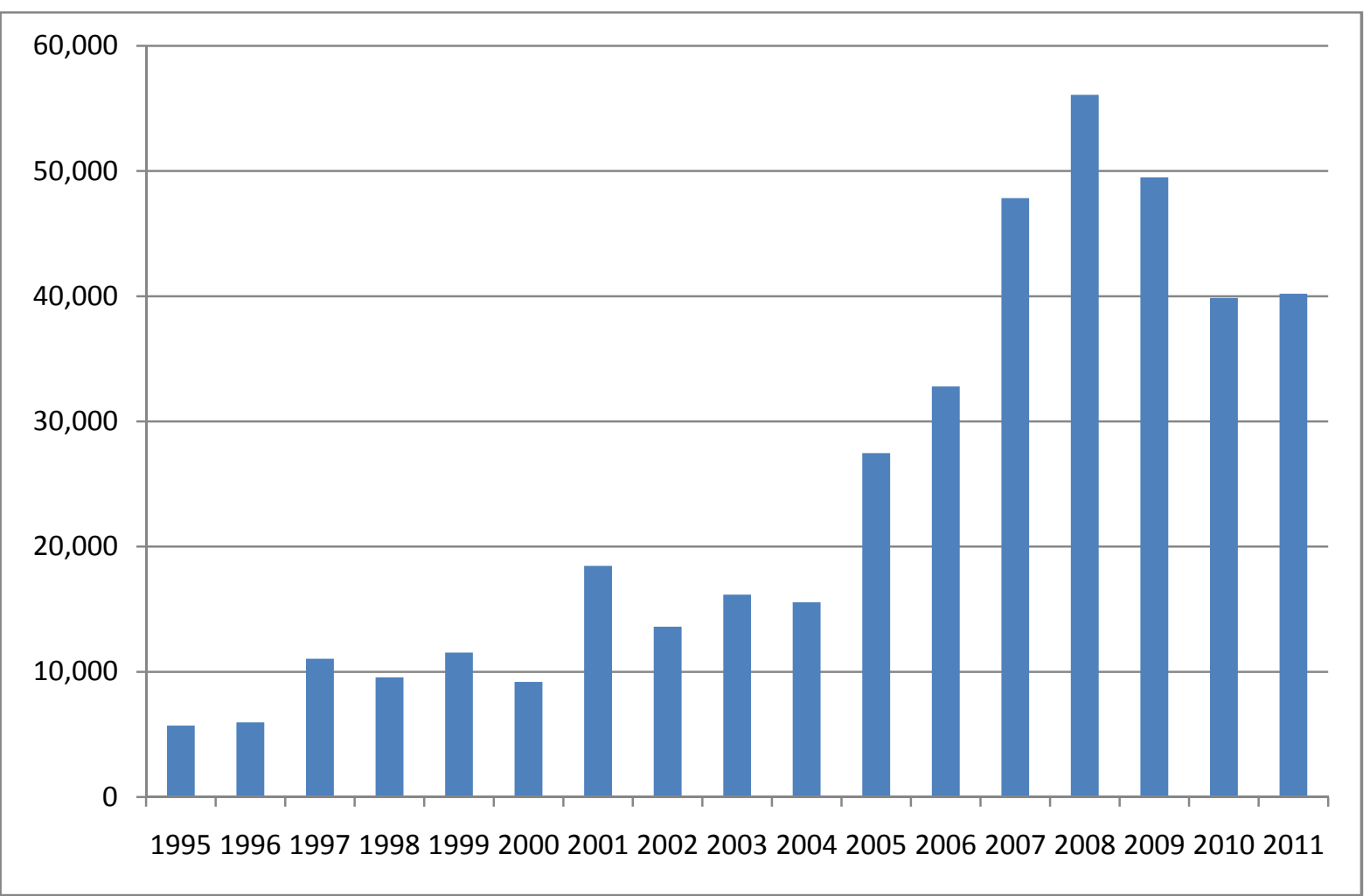

Figure 1. Inward FDI flow to Africa, 1995-2011 (at current prices and exchange rates, in millions of US dollar). Source: UNCTAD online database (Retrieved from http://unctadstat.unctad.org/).

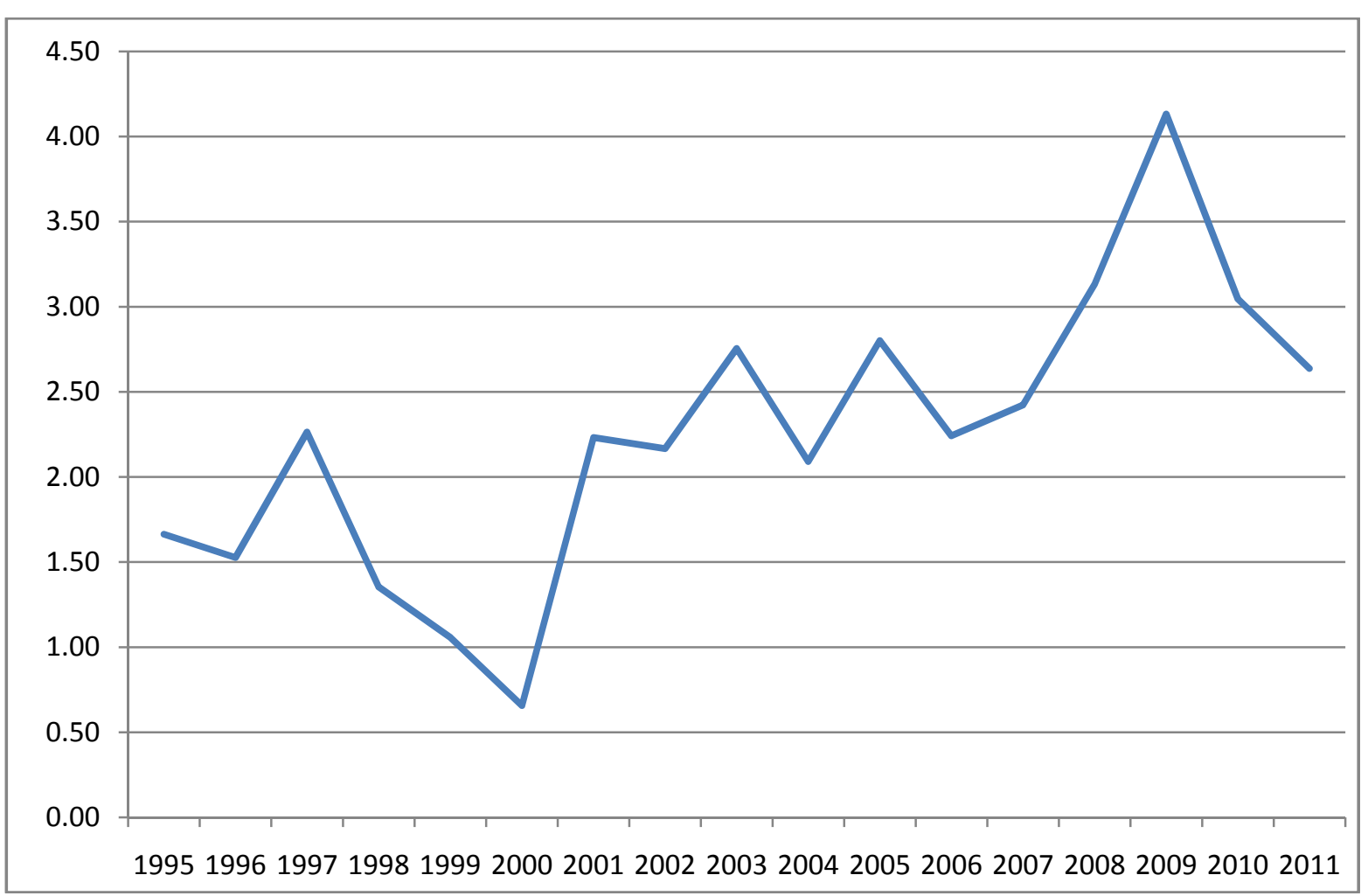

Figure 2. Africa's share of FDI in the world, 1995-2011 (\%). Source: UNCTAD online database (Retrieved from http://unctadstat.unctad.org/). 
The US has long been the dominant foreign investor abroad. China has just recently emerged as an important source of FDI. From a negligible amount of FDI in the beginning of the 1980s, China's outbound FDI rose to US\$2.9 billion in 2002 and then jump to US\$68.8 billion in 2010 (Ministry of Commerce (MOFCOM), 2010). Table 2 shows the US and Chinese FDI outflows in the recent past.

Table 2

US and Chinese FDI Outflows China, 2006-2010 (Millions)

\begin{tabular}{lcccccc}
\hline FDI & 2006 & 2007 & 2008 & 2009 & 2010 & $2006-2010$ Average \\
\hline Total US FDI & $\$ 224,220$ & $\$ 393,518$ & $\$ 308,296$ & $\$ 282,686$ & $\$ 328,905$ & $\$ 307,525$ \\
US FDI to Africa & $\$ 5,157$ & $\$ 4,490$ & $\$ 3,837$ & $\$ 8,652$ & $\$ 8,314$ & $\$ 6,090$ \\
US FDI to Africa (\%) & 2.30 & 1.14 & 1.24 & 3.06 & 2.53 & 2.05 \\
Total Chinese FDI & $\$ 17,634$ & $\$ 26,506$ & $\$ 55,907$ & $\$ 56,529$ & $\$ 68,811$ & $\$ 45,078$ \\
Chinese FDI to Africa & $\$ 520$ & $\$ 1,574$ & $\$ 5,491$ & $\$ 1,439$ & $\$ 2,112$ & $\$ 2,227$ \\
Chinese FDI to Africa (\%) & 2.95 & 5.94 & 9.82 & 2.55 & 3.07 & 4.86
\end{tabular}

Note. Source: UNCTAD online database (Retrieved from http://unctadstat.unctad.org/TableViewer/tableView.aspx) and OECD online database (Retrieved from http://www.oecd.org/statistics/).

During the period for which comparable data can be found, US outward FDI flow in 2006-2010 averaged about \$307 billion while the corresponding figure for China was only \$45 billion. In 2006, China’s FDI outflow was only $8 \%$ of the US outward FDI, but it is now about $20 \%$ of US FDI. Only a small fraction of the aggregate US and Chinese FDI was directed to Africa. During 2006-2010, the US FDI in Africa averaged \$6.1 billion, while the corresponding figure for China was \$2.2 billion. In 2010, US FDI flow to Africa was $\$ 8.3$ billion, four times more than the Chinese investment of $\$ 2.1$ billion. Africa's share of Chinese investment has been higher in percentage terms (unusually high investment in 2008 boosted the average figure) though. Overall, these figures clearly show that Africa attracts only a small fraction of FDI from both China and the US

\section{A Brief Review of the Literature}

The literature on the determinants of FDI is quite extensive. A brief overview of some of the main strands of literature is presented below. Hymer's (1976) doctoral dissertation pioneered the modern theory of FDI, arguing that market imperfection, rather than portfolio investment, is the main driving force of FDI flows. Dunning (1988), a major contributor in the FDI literature, provides an eclectic paradigm that generates four different motives for FDI: market-seeking (investment aimed at gaining access to new markets); resource-seeking (investment aimed at gaining access to raw materials); asset-seeking (investment aimed at gaining access to knowledge and technological know-how); and efficiency-seeking (investment aimed at cost reduction). More recent literature puts forward new categorizations that complement and extend previous ones. For example, Broadman (2007) defined three groups of factors to affect FDI flows. These are: "at-the-border" policies (tariff, quota, trade, and investment agreements); "behind-the-border" conditions (market structure, infrastructure, macroeconomic environment, and the quality of institutions); and "between-the-border" conditions (logistical simplifications, ethnic networks). Different host country characteristics would therefore attract different types of FDI. Another approach to explaining FDI is found in the process theory of internationalization, originally stimulated by the work of Johanson and Vahlne (1977) writing. 


\section{The Determinants of FDI: Hypotheses}

The paper now reviews the determinants of FDI derived from theory and hypotheses. Host market characteristics, such as market size, per capita growth, and host market growth, are generally found to be significant determinants of FDI flows, a result that is in line with the traditional FDI theory. For example, Buckley et al. (2007), Cheng and Ma (2008), and Cheung and Qian (2009) found significant positive relations between FDI flows and market size for Chinese FDI flows. In this research, GDP is used as a measure of the market size of the host country. Almost all empirical studies of the determinants of FDI include host country GDP as a measure of market size and this paper also does the same. In line with the literature, the paper expects a positive relationship between FDI and market size. Thus:

Hypothesis 1: FDI is associated positively with host country GDP.

Location-specific advantages are of considerable importance in explaining the rationale for and the direction of FDI (Dunning, 1993). Thus, the availability of natural resources, such as oil and other minerals, which are by their character specific to certain locations, will encourage foreign firms to undertake FDI. Thus, the paper expects a positive association between the countries' natural resource endowment and inward FDI (Buckley \& Casson, 1976). As a proxy for natural resources, the paper includes the share of fuels, ores, and metals in total merchandise exports by the host country.

Hypothesis 2: FDI is associated positively with host country fuels, ores, and metals in total merchandise exports.

With respect to strategic-asset seeking motive, FDI may be motivated by the desire to gain access to knowledge (i.e., marketing and manufacturing) and technological know-how (i.e., software). Buckley et al. (2007) and Kolstad and Wii (2011) had used the number of patents registered by the host country as a sign of the availability of strategic assets. But this may not be an appropriate proxy in this case since the focus is on the countries that are not particularly known to be home to strategic assets. The paper uses gross school enrolment as a proxy for strategic asset (Kudriavceva, 2011). Thus, a country with a higher gross school enrolment will have higher levels of human development, and thus a higher level of strategic assets.

Hypothesis 3: FDI is associated positively with host country gross school enrolment.

Trade ratio (also called openness index) is a common measure of globalization and a widely used indicator of acceptance of foreign investment (Ali, Fiess, \& MacDonald, 2011). Trade ratio is defined as export and import as a ratio of GDP. A higher level of openness is a sign of higher level of acceptance of inward FDI (Kudriavceva, 2011).

Hypothesis 4: FDI is associated positively with the trade ratio of the host country.

Inflation is a standard measure of macroeconomic performance. High inflation rates signal unstable economic conditions, poor fundamentals, and future currency depreciation, making it difficult for companies to set prices and estimate future profits (Asiedu, 2006; Poushahabi, Mahmoudinia, \& Soderjani, 2011). Thus, high inflation may negatively affect FDI inflows. Thus:

Hypothesis 5: FDI is associated negatively with host country inflation.

Political risk has long been recognized as an important determinant of FDI. Poor institutional development and high risk deter foreign investment (Cheung \& Qian, 2009). While Buckley et al. (2007) and Kolstad and Wii (2011) found that more Chinese investment went to countries with poor institutions, particularly during the 1992-2001 period, Cheung and Qian (2009) found that institutions played an insignificant role in attracting FDI 
flows. In line with the FDI literature, a measure of political risk is included in the model developed in this research. The expected relationship therefore remains indeterminate. Thus:

Hypothesis 6: FDI is associated negatively or positively with host country political risk.

FDI studies have long incorporated corruption as a determinant of FDI flow but there is still no agreement if corruption increases or decreases the FDI flow. For example, Habib and Zurawicki (2002), Javorcik and Wei (2009), and Barassi and Zhou (2012) found that corruption in a country acts like a "grabbing-hand" that increases the cost of doing business and thus discourages FDI inflows. On the other hand, Bjorvatn and Soreide (2005) and Shah (2001) argued that corruption can be a "helping-hand" and become an efficient "lubricant" for rigid regulation and red-tape and thus encourage FDI. Thus, the expected relationship remains indeterminate.

Hypothesis 7: FDI is associated negatively or positively with host country corruption.

\section{The Model}

Since there is no widely accepted structural model of FDI, the empirical analysis presented here is based on estimating a basic ad-hoc single-equation model that includes the arguments discussed in the previous section to explain the variation in FDI inflows in a broad range of countries, and African countries in particular. Based on specifications of past studies following semi-logarithmic equation is estimated:

USFDIi (or CHFDIi $)=a+\beta_{1}$ LGDPi $+\beta_{2}$ FOMi $+\beta_{3}$ Enrolmenti $+\beta_{4}$ TGDPi $+\beta_{5}$ Inflationi $+\beta_{6}$ PolRiski $+\beta_{7}$ CorPIi $+\beta_{8}$ Phonei $+\varepsilon_{i}$

Table 3 lists the variable names, definitions, and sources. Hypotheses were tested using ordinary least squares regression methods. Data are averages for the period 2003-2010. This will ensure that results are not affected by year-specific idiosyncratic spikes in the investment data. The availability of a consistent data set dictated the choice of time period. China has published internationally comparable (i.e., consistent with OECD and IMF standard) outward FDI data since 2003 only. The latest year for which data can be found as of now is 2010. After eliminating observations with missing figures and outliers (i.e., investments in Cayman Islands), the paper ends up with 87 to 97 usable observations.

Two important data issues require comments. First, unlike the US outward investments, many of the Chinese investments are undertaken by state-owned companies. Consequently, Chinese outward investment destinations may be influenced by the "Going Global" strategy adopted by the Chinese authorities. It is quite possible that Chinese outward FDI follows the state-driven strategy of giving infrastructure and natural resource investments a priority. Second, multinational institutions from which the data are obtained do not collect data themselves. They rely on data gathered by national statistical agencies, which often use different concepts, statistical coverage, and methods of data collection. These data limitations are recognized, documented, and discussed in the annual statistical reports of the multilateral institutions. Despite these limitations, data compiled by these institutions are the best set of statistical data available for cross-country studies.

Table 4 reports some descriptive statistics. The correlation matrix is presented in Table 5. Tables 4 and 5 indicate that there are no general problems with the data. Table 6 presents the main results from the econometric analysis, where the 2003-2010 period averages of outward FDI in China and the US are regressed on averages of the explanatory variables. 
Table 3

Variable List, Description, and Data Sources

\begin{tabular}{|c|c|c|c|}
\hline Variable & Description & Expected sign & Source \\
\hline $\begin{array}{l}\text { USFDI } \\
\text { (dependent } \\
\text { variable) }\end{array}$ & $\begin{array}{l}\text { Log of 2003-2010 average US FDI outflow in } \\
\text { millions in } 2005 \text { constant dollar. Raw data were first } \\
\text { deflated by the US CPI with } 2005 \text { as the base year. }\end{array}$ & & $\begin{array}{lr}\text { UNCTAD } & \text { online } \\
\text { (Retrieved } & \text { database } \\
\text { http://unctad.org/en/Pages/Statistics. } \\
\text { aspx). }\end{array}$ \\
\hline $\begin{array}{l}\text { CHFDI } \\
\text { (dependent } \\
\text { variable) }\end{array}$ & $\begin{array}{l}\text { Log of } 2003-2010 \text { average Chinese outward FDI } \\
\text { flows in millions in constant } 2005 \text { dollar. After } \\
\text { obtaining the data from the source, which are in } \\
\text { current dollars, they are then deflated by the Chinese } \\
\text { CPI with } 2005 \text { as the base year. }\end{array}$ & & $\begin{array}{l}2010 \text { and } 2009 \text { Statistical Bulletin of } \\
\text { China's Outward Foreign Direct } \\
\text { Investment, MOFCOM. }\end{array}$ \\
\hline LGDP & $\begin{array}{l}\text { Log of 2003-2010 average gross domestic product, } \\
\text { PPP (constant } 2005 \text { international \$). }\end{array}$ & + & $\begin{array}{lrr}\text { World } & \text { Development } & \text { Indicator, } \\
\text { World Bank online } & \text { database } \\
\text { (Retrieved } & \text { from } \\
\text { http://databank.worldbank.org/ddp/ } \\
\text { home.do?Step=12\&id=4\&CNO=2). }\end{array}$ \\
\hline FOM & $\begin{array}{l}\text { 2003-2010 average fuel, ore, and mineral exports } \\
\text { as \% of merchandise export. }\end{array}$ & + & Same as above \\
\hline Enrolment & 2003-2010 average gross secondary enrolment ratio. & + & Same as above \\
\hline TGDP & 2003-2010 average trade to GDP ratio. & + & Same as above \\
\hline Inflation & 2003-2010 average consumer price index. & - & Same as above \\
\hline Phone & 2003-2010 average telephone lines (per 100 people). & + & Same as above \\
\hline PolRisk & 2003-2010 average country risk rating. & - & $\begin{array}{llr}\text { The PRS } & \text { Group, International } \\
\text { Country Risk Guide (ICRG), various } \\
\text { years } \quad \text { (Retrieved r from } \\
\text { http://www.prsgroup.com/). } \\
\end{array}$ \\
\hline CorPI & 2003-2010 average corruption perception index. & ? & \begin{tabular}{|llr}
$\begin{array}{l}\text { Transparency } \\
\text { database }\end{array}$ & $\begin{array}{l}\text { International } \\
\text { (Retrieved }\end{array}$ & $\begin{array}{r}\text { online } \\
\text { from }\end{array}$ \\
http://www.transparency.org/). & \\
\end{tabular} \\
\hline Africa & Dummy variable, 1 = Yes, 0 = Otherwise. & ? & African Development Bank \\
\hline
\end{tabular}

Table 4

Descriptive Statistics (Full Sample)

\begin{tabular}{|c|c|c|c|c|c|}
\hline Variable name & $N$ & Mean & Standard deviation & Minimum & Maximum \\
\hline PolRisk & 139 & 66.3734 & 12.8473 & 24.0000 & 92.1000 \\
\hline USFDI & 127 & 2.0257 & 1.3211 & -0.8539 & 4.5876 \\
\hline CHFDI & 152 & 0.7404 & 1.2027 & -2.7081 & 4.1703 \\
\hline LGDP & 184 & 10.5540 & 0.9732 & 8.3369 & 13.1038 \\
\hline TGDP & 185 & 93.3965 & 51.2471 & 0.2496 & 411.5130 \\
\hline Inflation & 181 & 35.4437 & 393.8705 & -0.1155 & 5304.7810 \\
\hline Phone & 207 & 20.7816 & 19.6234 & 0.0333 & 87.8001 \\
\hline PolRisk & 139 & 66.3734 & 12.8473 & 24.0000 & 92.1000 \\
\hline CorPI & 175 & 3.9834 & 2.0673 & 1.1000 & 9.3000 \\
\hline FOM & 174 & 23.4600 & 28.3565 & 0.0001 & 98.1137 \\
\hline Enrolment & 184 & 76.2148 & 28.2327 & 7.7899 & 134.3010 \\
\hline Africa & 216 & 0.2500 & 0.4340 & 0.0000 & 1.0000 \\
\hline
\end{tabular}

Note. Own calculation based on the results from STATA. 
Table 5

Correlation Matrix

\begin{tabular}{|c|c|c|c|c|c|c|c|c|c|}
\hline Variable name & CHFDI & USFDI & LGDP & FOM & TGDP & Inflation & PolRisk & CorPI & Africa \\
\hline CHFDI & 1.0000 & & & & & & & & \\
\hline USFDI & 0.5072 & 1.0000 & & & & & & & \\
\hline LGDP & 0.4954 & 0.6911 & 1.0000 & & & & & & \\
\hline FOM & 0.1632 & -0.0504 & -0.1356 & 1.0000 & & & & & \\
\hline TGDP & 0.0081 & 0.0221 & -0.3854 & -0.1588 & 1.0000 & & & & \\
\hline Inflation & -0.0461 & -0.3656 & -0.2076 & 0.1665 & -0.1917 & 1.0000 & & & \\
\hline PolRisk & -0.0446 & 0.3187 & 0.1054 & -0.2269 & 0.3105 & -0.6796 & 1.0000 & & \\
\hline CorPI & 0.0484 & 0.3828 & 0.1357 & -0.2321 & 0.1607 & -0.5837 & 0.8643 & 1.0000 & \\
\hline Africa & 0.0788 & -0.2861 & -0.1840 & 0.1187 & -0.1618 & 0.1886 & -0.2911 & -0.2376 & 1.0000 \\
\hline
\end{tabular}

Note. Own calculation based on the results from STATA.

Table 6

Determinants of US and Chinese OFDI to World, Africa, and MENA, 2003-2010

\begin{tabular}{|c|c|c|c|c|}
\hline \multirow{2}{*}{ Variable name } & $(1.1)$ & $(1.2)$ & $(2.1)$ & $(2.2)$ \\
\hline & USFDI & CHFDI & USFDI & CHFDI \\
\hline \multirow[t]{2}{*}{ LGDP } & $1.3420^{* * *}$ & $1.2760^{* * *}$ & $1.3310^{* * * *}$ & $1.3340^{* * * *}$ \\
\hline & (9.493) & (8.178) & $(9.471)$ & (8.448) \\
\hline \multirow[t]{2}{*}{ FOM } & $0.0067^{* *}$ & $0.0105^{* * *}$ & $0.0069^{* *}$ & $0.0104^{* * *}$ \\
\hline & $(2.270)$ & (3.357) & (2.359) & (3.389) \\
\hline \multirow[t]{2}{*}{ Enrolment } & -0.0072 & $-0.0157^{* * *}$ & -0.0099 & -0.0098 \\
\hline & $(-1.115)$ & $(-2.647)$ & $(-1.488)$ & $(-1.439)$ \\
\hline \multirow[t]{2}{*}{ TGDP } & $0.0075^{* * *}$ & $0.0107^{* * *}$ & $0.0071^{* * *}$ & $0.0116^{* * *}$ \\
\hline & (3.320) & (4.113) & (3.148) & $(4.416)$ \\
\hline \multirow[t]{2}{*}{ Inflation } & -0.0205 & 0.0115 & -0.0191 & 0.0117 \\
\hline & $(-0.794)$ & $(0.468)$ & $(-0.746)$ & $(0.481)$ \\
\hline \multirow[t]{2}{*}{ PolRisk } & -0.0078 & $-0.0315^{*}$ & -0.0064 & $-0.0337^{*}$ \\
\hline & $(-0.439)$ & $(-1.778)$ & $(-0.364)$ & $(-1.918)$ \\
\hline \multirow[t]{2}{*}{ CorPI } & $0.1480^{*}$ & $0.2720^{* * *}$ & $0.1660^{* *}$ & $0.2440^{* * *}$ \\
\hline & (1.922) & (3.086) & (2.149) & $(2.758)$ \\
\hline \multirow[t]{2}{*}{ Phone } & 0.0040 & -0.0131 & 0.0014 & -0.0105 \\
\hline & $(0.466)$ & $(-1.349)$ & $(0.160)$ & $(-1.079)$ \\
\hline \multirow[t]{2}{*}{ Africa } & & & -0.4230 & $0.5480^{*}$ \\
\hline & & & $(-1.456)$ & (1.728) \\
\hline \multirow[t]{2}{*}{ Constant } & $-13.06^{* * *}$ & $-12.15^{* * *}$ & $-12.75^{* * *}$ & $-13.26^{* * *}$ \\
\hline & $(-6.568)$ & $(-6.082)$ & $(-6.418)$ & $(-6.383)$ \\
\hline$F$ & 16.39 & 10.65 & 15.02 & 10.01 \\
\hline$N$ & 87 & 97 & 87 & 97 \\
\hline Adjusted $R$-squared & 0.5888 & 0.4456 & 0.5946 & 0.4579 \\
\hline
\end{tabular}

Notes. $t$-statistics in parentheses; ${ }^{* * *} p<0.01,{ }^{* *} p<0.05,{ }^{*} p<0.1$. Dependent variables: USFD: US outward foreign direct investment; CHFDI: Log of Chinese outward foreign direct investment. 
All estimates are corrected for Heteroscedasticity by utilizing White's consistent estimator of the covariance matrix. The general fit of the model as represented by the adjusted $R$-squares is reasonable. The likelihood ratio test of the hypothesis that all coefficients are jointly equal to zero can be rejected at the $5 \%$ level. Akaike information criterion and the Schewarz criterion indicate the absence of specification error. The variance inflation factor test scores are all below 5, indicating the absence of multicollinearity problem.

Estimation results show some general pattern. Market size (LGDP) has a significant positive impact on both the US and Chinese FDI outflows to the world and African countries. This indicates that market seeking was a major motive for both countries in the period under study. Natural resource availability (FOM) has a significant positive influence, at least at the 5\% level, on the US and Chinese outward ODI in all areas. This means that the location-specific advantage motive of FDI was important for both countries. The paper finds evidence that the exports of natural resources attract the extra amount of FDI from the US and China. In other words, Chinese FDI responded to the location-specific advantage the same way the US FDI responded. But the Chinese FDI responded more strongly than the US FDI flows. Trade ratio (TGDP) is found to have a significant and positive effect on both countries' FDI flows. This means that, on the average, the higher the trade ratio (export and import as a ratio of GDP) of a country, the higher the FDI flow to this country.

Corruption perception index, published by the Transparency International, is defined as "perceived levels of corruption, as determined by expert assessments and opinion surveys". The CPI generally defines corruption as "the misuse of public power for private benefit". The CPI ranks countries "on a scale from 10 (very clean) to 0 (highly corrupt)". According to this investigation, CorPI (level of corruption) has a significant positive influence, at least at the 5\% level, on outward FDI flows for both countries. This paper's finding contradicts with the popular perception that Chinese outward FDI ignores corruption or attracted to countries with higher levels of corruption (keep in mind that a lower CPI indicates a higher level of corruption).

Political risk index, published annually by the PRS Group, ranks countries on the risk of incurring losses when investing in a foreign country as a result of changes in the country's political structure or policies, such as tax laws, tariffs, expropriation of assets, restriction on repatriation of profits, or episodes of political violence. The index varies from 0 (high risk) to 100 (low risk), indicating higher values to greater political stability. According to this paper's estimation, the coefficient on the index of political risk shows a negative sign for all models, but not significant for the US and weakly significant (10\% level) for Chinese only. High political risk should be associated with low values of FDI and the paper finds evidence for it the case for China. This contradicts the general perception that higher level of Chinese outward FDI is associated with the rising level of host country political risk (lower level of index number), albeit somewhat weakly. In other words, as far as political risk is concerned, the Chinese FDI flow is not different from the US FDI flow.

The coefficients on the Enrolment (asset-seeking motive) show mixed results, significant for Chinese FDI and not for US FDI. The coefficients on the Inflation (macroeconomic stability) show negative signs for the US and a positive sign for China, but it is not significant in any case. This means that in general the US and Chinese outward FDI flows are insensitive to macroeconomic stability in a foreign country.

The sign for dummy variable for Africa is positive and significant at the 10 level of Chinese FDI. This means that compared to the non-African countries (the benchmark group), Chinese investment in Africa is slightly higher $(-12.322=-12.6402+0.604)$, other things remaining the same. In the case of the US FDI, the 
sign for dummy variable for Africa is positive, but insignificant, indicating that the US FDI investment is lower compared to the benchmark group.

\section{Conclusions}

This paper is one of the first attempts to formally compare the patterns of the US and Chinese outward FDI. The objective is to examine if the motives for FDI for these two countries differ. The paper did this first with some descriptive statistics and then running OLS regressions on a set of explanatory variables derived from the FDI literature. It finds expected result for market size, resource endowment, corruption, and openness. Chinese investment in Africa is often viewed as their desire to control natural resources, but it finds that the US investment is no different in this regard. With respect to political risk, both the US and Chinese investment flows decline with rise in political risk.

\section{References}

Ali, F., Fiess, N., \& MacDonald, R. (2011). Climbing to the top? Foreign direct investment and property rights. Economic Inquiry, 49(1), 289-302.

Asiedu, E. (2006). Foreign direct investment in Africa: The role of natural resources, market size, government policy, and political instability. World Development, 29, 63-77.

Barassi, M. R., \& Zhou, Y. (2012). The effect of corruption on FDI: A parametric and non-parametric analysis. European Journal of Political Economy, 28, 302-312.

Bhaumik, S., \& Co, C. Y. (2009). Chinese state’s economic cooperation related investment: An investigation of its direction and some implications for outward investment. William Davidson Institute Working Paper Number 966.

Bjorvatn, K., \& Soreide, T. (2005). Corruption and privatization. European Journal of Political Economy, $21,903-914$.

Broadman, H. G. (2007). Africa's silk road: China and India's new economic frontier. Washington: World Bank.

Buckley, P., \& Casson, M. (1976). The future of the multinational enterprise. Macmillan: London.

Buckley, P., Clegg, J., Cross, A., Liu, X., Voss, H., \& Zheng, P. (2007). The determinants of Chinese outward foreign direct investment. Journal of International Business Studies, 38, 499-518.

Cheng, L., \& Ma, Z. (2008). China's outward foreign direct investment. Delhi, India: Indian Statistical Institute.

Cheung, Y., \& Qian, X. (2009). Empirics of China’s outward direct investment. Pacific Economic Review, 14(3), $312-341$.

Dunning, J. (1988). The eclectic paradigm of international production: A restatement and some possible extensions. Journal of International Business Studies, 19(1), 1-31.

Dunning, J. (1993). Multinational enterprises and the global economy. Wokingham, England: Addison-Wesley.

Habib, M., \& Zurawicki, L. (2002). Corruption and foreign direct investment. Journal of International Business Studies, 3 , 291-307.

Hymer, S. (1976). The international operations of national firms: A study of direct foreign investment. Cambridge, M.A.: MIT Press.

Javorcik, B., \& Wei, S. (2009). Corruption and cross-border investment in emerging markets: Firm level evidence. Journal of International Money and Finance, 28, 605-624.

Johanson, J., \& Vahlne, J. E. (1977). The internationalization process of the firm: A model of knowledge development and increasing foreign market commitments. Journal of International Business Studies, 8(1), 23-52.

Kolstad, I., \& Wii, A. (2011). Better the devil you know? Chinese foreign direct investment in Africa. Journal of African Business, 12, 31-50.

Kudriavceva, N. (2011). The determinants of foreign direct investment in central and eastern Europe. Retrieved from http://ssrn.com/abstract=2007606

Ministry of Commerce (MOFCOM). (2010). 2010 statistical bulletin of China's outward foreign direct investment, People's Republic of China. Retrieved from http://english.mofcom.gov.cn/aarticle/statistic/foreigninvestment/201109/20110907742320.html

Political Risk Service Group. (various years). Country reports. Retrieved from http://www.prsgroup.com/ 
Poushahabi, F., Mahmoudinia, D., \& Soderjani, E. (2011). FDI, human capital, economic freedom and growth in OECD countries. Research Journal of International Studies, 19, 71-81.

Shah, B. (2001). Red tape, incentive bribe and the provision of subsidy. Journal of Development Economics, 65, 113-133.

Transparency International. (various years). Corruption perception index. Retrieved from http://www.transparency.org/

United Nations Conference on Trade and Development. (2012). World investment report. Retrieved from http://unctad.org/en/Pages/DIAE/World\%20Investment\%20Report/WIR2012_WebFlyer.asp

United Nations Conference on Trade and Development. (various years). UNCTAD statistics. Retrieved from http://unctad.org/en/Pages/Statistics.aspx

World Bank. (various years). World development indicators. Retrieved from http://databank.worldbank.org/ddp/home.do?Step=12\&id=4\&CNO=2 